\title{
The role of ascitic fluid viscosity in the differential diagnosis of ascites
}

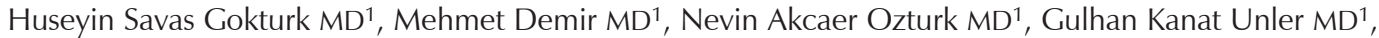 \\ Sevsen Kulaksizoglu MD², Ilknur Kozanoglu MD³ , Ender Serin MD', Ugur Yilmaz MD
}

HS Gokturk, M Demir, NA Ozturk, et al. The role of ascitic fluid viscosity in the differential diagnosis of ascites. Can J Gastroenterol 2010;24(4):255-259.

BACKGROUND: Ascites is defined as the pathological accumulation of fluid in the peritoneal cavity. It is the most common complication of cirrhosis, which is also the most common cause of ascites. Viscosity is a measure of the resistance of a fluid to deform under shear stress. Plasma viscosity is influenced by the concentration of plasma proteins and lipoproteins, with the major contribution from fibrinogen. To our knowledge, the viscosity of ascitic fluid has not yet been studied.

OBJECTIVE: To evaluate the role of ascitic fluid viscosity in discriminating between ascites due to portal hypertension-related and nonportal hypertension-related causes, and to compare results with the serum-ascites albumin gradient (SAAG).

METHODS: The present study involved 142 patients with ascites presenting with diverse medical problems. Serum total protein, albumin, glucose, lactate dehydrogenase (LDH) levels and complete blood count were obtained for all subjects. Paracentesis was performed routinely on admission and all ascitic fluid samples were evaluated by manual cell count with differential, ascitic fluid culture and biochemistry (total protein, albumin, glucose and LDH). Cultures of ascitic fluid were performed at bedside in all patients using blood culture bottles. Ascitic fluid viscosity was measured in a commercially available cone and plate viscometer.

RESULTS: Of the 142 patients studied, 34 (24\%) had an SAAG of $11 \mathrm{~g} / \mathrm{L}$ or less, whereas $108(76 \%)$ had an SAAG of greater than $11 \mathrm{~g} / \mathrm{L}$. Sex and mean age did not differ significantly between the two groups $(\mathrm{P}>0.05)$. Serum total protein, albumin, glucose, LDH levels, leukocyte count, ascitic fluid glucose levels and ascitic fluid leukocyte counts were similar in both groups, with no statistically significant relationship detected $(\mathrm{P}>0.05)$. However, the mean $( \pm \mathrm{SD})$ ascitic fluid total protein $(0.0172 \pm 0.1104 \mathrm{~g} / \mathrm{L}$ versus $0.043 \pm 0.011 \mathrm{~g} / \mathrm{L})$, albumin $(0.0104 \pm 0.0064 \mathrm{~g} / \mathrm{L}$ versus $0.0276 \pm 0.0069 \mathrm{~g} / \mathrm{L})$ and $\mathrm{LDH}$ $(102.76 \pm 80.95 \mathrm{U} / \mathrm{L}$ versus $885.71 \pm 199.93 \mathrm{U} / \mathrm{L})$ were found to be higher in patients with an SAAG of $11 \mathrm{~g} / \mathrm{L}$ or less than in those with an SAAG of greater than $11 \mathrm{~g} / \mathrm{L}(\mathrm{P}<0.001)$. The mean ascitic fluid viscosities were $0.86 \pm 0.12$ centipoise $(\mathrm{cP})$ and $1.22 \pm 0.25 \mathrm{cP}$ in patients with an SAAG greater than $11 \mathrm{~g} / \mathrm{L}$ and an SAAG of $11 \mathrm{~g} / \mathrm{L}$ or less, respectively $(\mathrm{P}<0.001)$. Although ascitic fluid infection was detected in 35 patients (24.6\%) (19 patients with spontaneous bacterial peritonitis, seven patients with culture-negative neutrocytic ascites, three patients with monobacterial non-neutrocytic bacterascites and six patients with secondary bacterial peritonitis), no significant effect on ascitic fluid viscosity was detected. Multiple linear regression analysis revealed that ascitic fluid total protein, albumin and LDH levels were independent predictors of ascitic fluid viscosity $(\mathrm{P}<0.001)$. The sensitivity, specificity, and positive and negative predictive values of ascitic fluid viscosity for the discrimination between ascites due to portal hypertension-related and nonportal hypertension-related causes according to the SAAG were determined by receiver operating characteristic analysis. Regarding the cut-off value of $1.03 \mathrm{cP}$, ascitic fluid viscosity measurement had a high sensitivity, specificity (98\% and $80 \%$, respectively), and positive and negative predictive value ( $79 \%$ and $94 \%$, respectively) for the etiological discrimination of ascites.

CONCLUSION: The measurement of ascitic fluid viscosity correlates significantly with SAAG values. In view of its simplicity, low cost, small sample volume requirement and allowance for measurement in previously frozen samples, measurement of ascites viscosity could be useful for the accurate and rapid classification of ascites.

Key Words: Ascites; Serum-ascites albumin gradient; Viscosity

\section{Le rôle de la viscosité du liquide d'ascite dans le diagnostic différentiel de l'ascite}

HISTORIQUE : L'ascite se définit comme l'accumulation pathologique de liquide dans la cavité péritonéale. C'est la principale complication de la cirrhose, qui est également la principale cause d'ascite. La viscosité est une mesure de la résistance d'un liquide à se déformer en cas de contrainte de cisaillement. La viscosité du plasma est influencée par la concentration de protéines plasmatiques et des lipoprotéines, avec l'apport majeur du fibrogène. En autant que nous le sachions, la viscosité du liquide d'ascite n'a pas encore fait l'objet d'études.

OBJECTIF : Évaluer le rôle de la viscosité du liquide d'ascite pour distinguer l'ascite liée à l'hypertension portale de celle qui ne l'est pas et comparer les résultats avec le gradient d'albumine entre le sérum et l'ascite (GASA).

MÉTHODOLOGIE : La présente étude portait sur 142 patients ayant une ascite se manifestant par divers problèmes de santé. Les auteurs ont obtenu les taux de protéine sérique totale, d'albumine, de glucose, de lacticodéshydrogénase (LDH) et la formule sanguine de tous les sujets. Ils effectuaient systématiquement une paracentèse à l'admission et évaluaient tous les prélèvements de liquide d'ascite par dénombrement cellulaire manuel et formule leucocytaire, culture du liquide d'ascite et biochimie (protéine totale, albumine, glucose et LDH). Ils effectuaient les cultures du liquide d'ascite au chevet de tous les patients, au moyen de bouteilles à hémoculture. Ils mesuraient la viscosité du liquide d'ascite dans un viscosimètre à cône et à plaque offert sur le marché.

RÉSULTAT : Des 142 patients à l'étude, 34 (24\%) avaient un GASA maximal de $11 \mathrm{~g} / \mathrm{L}$, et 108 (76 \%), un GASA de plus de $11 \mathrm{~g} / \mathrm{L}$. Le sexe et l'âge moyen ne différaient pas de manière significative entre les deux groupes $(\mathrm{P}>0,05)$. Les taux de protéine sérique totale, d'albumine, de glucose et de $\mathrm{LDH}$, la leucocytémie, le taux de glucose du liquide d'ascite et la leucocytémie du liquide d'ascite étaient similaires dans les deux groupes, sans qu'on ait décelé de lien statistiquement significatif $(\mathrm{P}>0,05)$.

${ }^{1}$ Department of Gastroenterology; ${ }^{2}$ Department of Biochemistry; ${ }^{3}$ Department of Physiology, Baskent University Faculty of Medicine, Adana, Turkey

Correspondence: Dr Huseyin Savas Gokturk, Baskent University, Department of Gastroenterology, Konya Uygulama ve Araştrma Merkezi, Saray Cad. No:1, Selcuklu, 42080, Konya, Turkey. Telephone 90-332-2570606, fax 90-332-2570637, e-mail savasgokturk@yahoo.com

Received for publication April 29, 2009. Accepted July 26, 2009 

l'albumine et la LDS moyennes $( \pm E ́ T)(0,0172 \pm 0,1104 \mathrm{~g} / \mathrm{L}$ par rapport à $0,043 \pm 0,011 \mathrm{~g} / \mathrm{L}, 0,0104 \pm 0,0064 \mathrm{~g} / \mathrm{L}$ par rapport à $0,0276 \pm 0,0069 \mathrm{~g} / \mathrm{L}$ et $102,76 \pm 80,95 \mathrm{U} / \mathrm{L}$ par rapport à $885,71 \pm 199,93 \mathrm{U} / \mathrm{L}$, respectivement) étaient plus élevées chez les patients dont le GASA maximal était de $11 \mathrm{~g} / \mathrm{L}$ que chez ceux dont le GASA était supérieur à $11 \mathrm{~g} / \mathrm{L}(\mathrm{P}<0,001)$. Les

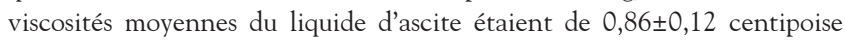
$1,22 \pm 0,25 \mathrm{cP}$ chez ceux dont le GASA maximal était de $11 \mathrm{~g} / \mathrm{L}(\mathrm{P}<0,001)$. Même si on a décelé une infection du liquide d'ascite chez 35 patients (24,6 \%) (19 patients ayant une péritonite bactérienne spontanée, sept, une ascite neutrocytique culture-négative, trois, une bactérascite non neutrocytique monobactérienne et six, une péritonite bactérienne secondaire), on n'a décelé aucun effet significatif de la viscosité du liquide d'ascite. L'analyse de régression linéaire multiple a révélé que les taux de protéine totale, d'albumine et de LDH du liquide d'ascite étaient des
Cependant, on a observé que la protéine totale de liquide d'ascite, $(\mathrm{cP})$ chez les patients dont le GASA était supérieur à $11 \mathrm{~g} / \mathrm{L}$ et de

prédicteurs indépendants de la viscosité du liquide d'ascite $(\mathrm{P}<0,001)$. La sensibilité, la spécificité et les valeurs prédictives positives et négatives de la viscosité du liquide d'ascite pour distinguer l'ascite liée à une hypertension portale d'une ascite qui ne l'est pas d'après le GASA étaient déterminées par une analyse de fonction d'efficacité du récepteur. Pour ce qui est de la valeur seuil de 1,03 cP, la mesure de viscosité du liquide d'ascite avait une sensibilité et une spécificité élevées ( $98 \%$ et $80 \%$, respectivement), et une valeur prédictive positive et négative ( $79 \%$ et $94 \%$, respectivement) pour la discrimination étiologique de l'ascite.

CONCLUSION : La mesure de la viscosité du liquide d'ascite est corrélée de manière significative avec les valeurs de GASA. Étant donné sa simplicité, son faible coût, le petit volume de prélèvement requis et la possibilité de faire les mesures à partir d'échantillons congelés, la mesure de la viscosité de l'ascite peut être utile pour classer l'ascite rapidement et avec exactitude.

The present study aimed to evaluate the role of ascitic fluid viscosity in discriminating between the ascites due to portal hypertension-related and nonportal hypertension-related causes, and to compare these results with the SAAG. fluid in the peritoneal cavity is defined as ascites; abscess formation and localized or cystic accumulations are not included in the definition of this term (1).

Ascites formation is the result of a series of anatomical, pathophysiological and biochemical changes. The specific causes of ascites can be divided into those associated with portal hypertension (cirrhotic ascites) and those unrelated to portal hypertension (noncirrhotic ascites). In patients with liver cirrhosis, ascites develops as a consequence of sinusoidal portal hypertension, which results in alterations to capillary pressure, permeability and accumulation of retained fluid in the abdominal cavity. This mechanism of fluid accumulation is known as transudation. The passage of high molecular weight substances is limited because capillary damage is not the underlying process in transudation. Another mechanism of ascites formation is known as exudation; ascites development is secondary to increased vascular permeability due to the inflammatory process, tumoral invasion, or traumatic damage to the peritoneum or intraperitoneal organs (1-3).

Many ascitic fluid tests have been proposed; however, a rational determination of the order of the tests should be made according to the clinical setting of each patient. The serumascites albumin gradient (SAAG), a parameter dependent on hydrostatic and oncotic pressure gradients between the intravascular area and serous cavities, is the difference between the albumin concentration in serum and ascitic fluid. A SAAG cutoff value of $11 \mathrm{~g} / \mathrm{L}$ has been shown to distinguish patients in whom ascites is secondary to portal hypertension and those without portal hypertension, with more than 97\% accuracy (4).

Viscosity can be described as the resistance of fluids to flow. It is one of the fundamental properties of a fluid that determines the nature of its flow. The viscosity of a fluid is defined as the ratio of shear stress to the shear rate. Plasma viscosity is a biochemically composite variable and is influenced by the concentration of plasma proteins and lipoproteins, of which fibrinogen is a major contributor. It has been shown that measuring plasma viscosity is a simple, reliable test, with no significant change in plasma viscosity when samples are stored frozen for up to 12 months $(5,6)$. Additionally, pleural fluid viscosity appears to provide better discrimination between transudative and exudative pleural effusions. However, the diagnostic utility of measuring ascitic fluid viscosity has yet to be studied.

\section{METHODS}

\section{Patients}

The present study included 142 patients with newly diagnosed ascites due to various causes who were referred and admitted to the gastroenterology unit of Baskent University Konya Hospital (Konya, Turkey) between September 2006 and December 2008. The diagnosis of ascites was based on clinical and biochemical findings.

Active infection requiring antibiotic therapy, acute or chronic renal failure, history of diuretic use in the preceding three months, psychiatric illnesses, coagulation abnormalities, and liver or renal transplantation were criteria for exclusion.

Evaluation of patients with ascites included standard hematology, electrolyte, lactate dehydrogenase (LDH), renal (serum creatinine and blood urea nitrogen), and coagulation (prothrombin time) and liver tests (aminotransferases, bilirubin, albumin, total protein and alkaline phosphatase). Abdominal ultrasonography and, if needed, other diagnostic radiological procedures were also performed. All patients in the present study underwent an interview and a review of their medical records. A diagnostic paracentesis, in which $30 \mathrm{~mL}$ of fluid was extracted, was performed. Tests on ascitic fluid samples included cell count, measurement of albumin, total protein, glucose and LDH; cultures were performed in blood culture bottles. A $5 \mathrm{~mL}$ sample of ascitic fluid was stored at $-20^{\circ} \mathrm{C}$ for viscosity measurements, which were all performed later the same day in the hematology laboratory of the Baskent University Adana Teaching and Medical Research Centre (Adana, Turkey).

Serum and ascitic fluid glucose, albumin and total protein levels were measured and analyzed using commercially available kits (Abbott Laboratories, USA) and the Abbott Aeroset autoanalyzer. Serum and ascitic fluid LDH levels were measured enzymatically using commercially available kits (Abbott Laboratories, USA) and the Aeroset autoanalyzer. Complete blood count measurements were performed with the Abbott Cell-DYN 3700 Hematology Analyzer (Abbott Laboratories, USA). 
TABLE 1

Demographic, rheological, hematological and biochemical characteristics of the study groups

\begin{tabular}{|c|c|c|c|}
\hline & \multicolumn{2}{|c|}{ Group } & \multirow[b]{2}{*}{$\mathbf{P}$} \\
\hline & SAAG >11 g/L & $\mathrm{SAAG} \leq 11 \mathrm{~g} / \mathrm{L}$ & \\
\hline Patients, n & 108 & 38 & \\
\hline Age, years & $56.8 \pm 11.3$ & $63.8 \pm 13.6$ & $>0.05$ \\
\hline Sex, male/female $(n / n)$ & $54 / 54$ & $20 / 18$ & $>0.05$ \\
\hline Ascitic fluid viscosity, $\mathrm{cP}$ & $0.86 \pm 0.12$ & $1.22 \pm 0.25$ & $<0.001$ \\
\hline Serum total protein, $\mathrm{g} / \mathrm{L}$ & $0.0639 \pm 0.0111$ & $0.0614 \pm 0.0095$ & $>0.05$ \\
\hline Serum albumin, g/L & $0.0324 \pm 0.0062$ & $0.0365 \pm 0.0062$ & $>0.05$ \\
\hline Serum glucose, mmol/L & $6.69 \pm 3.05$ & $6.67 \pm 1.234$ & $>0.05$ \\
\hline Serum LDH, U/L & $206.23 \pm 70.23$ & $243.00 \pm 72.94$ & $>0.05$ \\
\hline $\begin{array}{l}\text { Peripheral blood WBC } \\
\text { count, } \mathrm{mm}^{3}\end{array}$ & $7394.73 \pm 5935.96$ & $7862.10 \pm 3491.53$ & $>0.05$ \\
\hline Ascites total protein, $\mathrm{g} / \mathrm{L}$ & $0.0172 \pm 0.1104$ & $0.0430 \pm 0.0110$ & $<0.001$ \\
\hline Ascites albumin, g/L & $0.0104 \pm 0.0064$ & $0.0276 \pm 0.0069$ & $<0.001$ \\
\hline Ascites glucose, $\mathrm{mmol} / \mathrm{L}$ & $6.87 \pm 0.560$ & $1.12 \pm 2.53$ & $>0.05$ \\
\hline Ascites LDH, U/L & $102.76 \pm 80.95$ & $885.71 \pm 199.93$ & $<0.001$ \\
\hline $\begin{array}{l}\text { Ascitic fluid WBC count, } \\
\mathrm{mm}^{3}\end{array}$ & $517.92 \pm 1258.75$ & $1675.63 \pm 2850.64$ & $>0.05$ \\
\hline
\end{tabular}

Data are presented as mean $\pm S D$ unless indicated otherwise. $C P$ Centipoise; LDH Lactate dehydrogenase; WBC White blood cell; SAAG Serum-ascites albumin gradient

Measurement of ascitic fluid viscosity

Ascitic fluid viscosity was determined using standard technology in a programmable rotational viscometer (DV-III plus, Brookfield Laboratories, USA), which uses a cone-and-plate measuring head requiring $0.5 \mathrm{~mL}$ of sample fluid. The cone is coupled to a motor by a spring, the rotational speed of which can be preset, and determines the shear rate. All measurements were performed at $37^{\circ} \mathrm{C}$, with a shear rate of $450 \mathrm{~s}^{-1}$. The interassay coefficient of variation was $2 \%$. The viscosity measurement results were expressed as centipoise $(\mathrm{cP})$.

The study was approved by the local ethics committee of Baskent University. Each patient provided written informed consent in accordance with the Declaration of Helsinki.

\section{Statistical analysis}

Data were statistically analyzed using SPSS software version 13.0 (SPSS Inc, USA). Results were expressed as mean \pm SD. Categorical variables were analyzed using the $\chi^{2}$ test and continuous variables were analyzed using the Student's $t$ test. Associations determined by correlation analysis were expressed as a Pearson's correlation coefficient (r). Multivariable linear regression analysis was used to detect independent variables. A receiver operating characteristic (ROC) curve was created to determine the predictive power of ascitic fluid viscosity and a cut-off value was obtained. Subsequently, the sensitivity, specificity, and negative and positive predictive values of the obtained cut-off in the discrimination of ascitic fluid etiology were calculated. $\mathrm{P}<0.05$ was considered to be statistically significant.

\section{RESULTS}

The study population consisted of 142 patients with diverse ascitic etiologies. Of the 142 patients studied, 34 (24\%) had an SAAG of $11 \mathrm{~g} / \mathrm{L}$ or less whereas $108(76 \%)$ had an SAAG of greater than $11 \mathrm{~g} / \mathrm{L}$. The baseline characteristics of the two

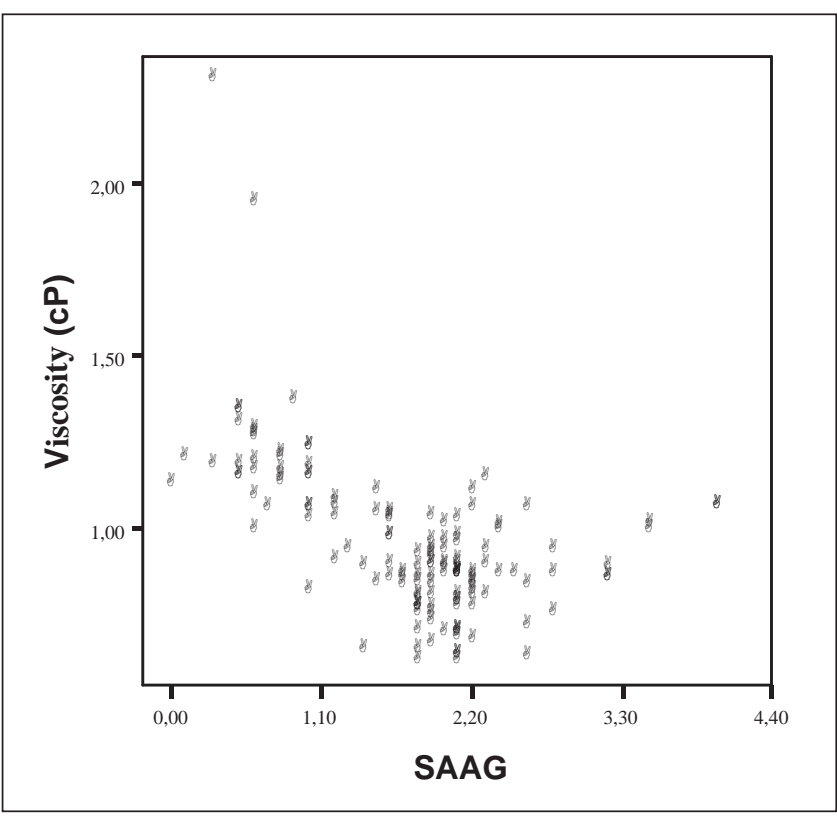

Figure 1) The distribution of serum-ascites albumin gradient (SAAG) versus ascitic fluid viscosity. cP Centipoise

groups are presented in Table 1. The etiologies of ascites in the group with a SAAG of greater than $11 \mathrm{~g} / \mathrm{L}$ were liver cirrhosis in 83 patients, congestive heart failure in 19 patients, mixed cause (liver cirrhosis and metastases to the liver) in four patients, Budd-Chiari syndrome in one patient and chylous ascites due to dilated cardiomyopathy in one patient. Of the ascitic patients with an SAAG of $11 \mathrm{~g} / \mathrm{L}$ or less, etiologies were peritonitis carcinomatosa in 18 patients, intestinal perforation in eight patients, necrotizing pancreatitis in five patients, tuberculous peritonitis in two patients and chylous ascites due to lymphoma in one patient. Sex and mean age did not differ significantly between the two groups $(\mathrm{P}>0.05)$. Serum total protein, albumin, glucose, LDH levels, leukocyte count, and ascitic fluid glucose levels and ascitic fluid leukocyte counts were similar in both groups, with no statistically significant differences $(P>0.05)$. However, the mean ascitic fluid total protein $(0.0172 \pm 0.1104 \mathrm{~g} / \mathrm{L}$ versus $0.0430 \pm 0.0110 \mathrm{~g} / \mathrm{L})$, albumin $(0.0104 \pm 0.0064 \mathrm{~g} / \mathrm{L}$ versus $0.0276 \pm 0.0069 \mathrm{~g} / \mathrm{L})$ and $\mathrm{LDH}$ $(102.76 \pm 80.95 \mathrm{U} / \mathrm{L}$ versus $885.71 \pm 199.93 \mathrm{U} / \mathrm{L})$ were found to be lower in patients with a SAAG of greater than $11 \mathrm{~g} / \mathrm{L}$ than in those with an SAAG of $11 \mathrm{~g} / \mathrm{L}$ or less, respectively; the difference between groups was statistically significant $(\mathrm{P}<0.001)$ (Table 1 ). The mean ascitic fluid viscosities were $0.86 \pm 0.12 \mathrm{cP}$ and $1.22 \pm 0.25 \mathrm{cP}$ in patients with a SAAG of greater than $11 \mathrm{~g} / \mathrm{L}$ and an SAAG of $11 \mathrm{~g} / \mathrm{L}$ or less, respectively $(\mathrm{P}<0.001)$ (Table 1$)$. The distribution of SAAG values versus ascitic fluid viscosity of the 142 subjects is presented in Figure 1.

Although ascitic fluid infection was detected in 35 (24.6\%) patients (19 patients with spontaneous bacterial peritonitis, seven patients with culture-negative neutrocytic ascites, three patients with monobacterial, non-neutrocytic bacterascites and six patients with secondary bacterial peritonitis), no significant effect of ascitic fluid infection on ascitic fluid viscosity was detected. Among the ascitic patients with an SAAG of greater than $11 \mathrm{~g} / \mathrm{L}$, liver cirrhosis and congestive heart failure patients constituted the vast majority of the group. Although the mean ascitic fluid viscosity was 


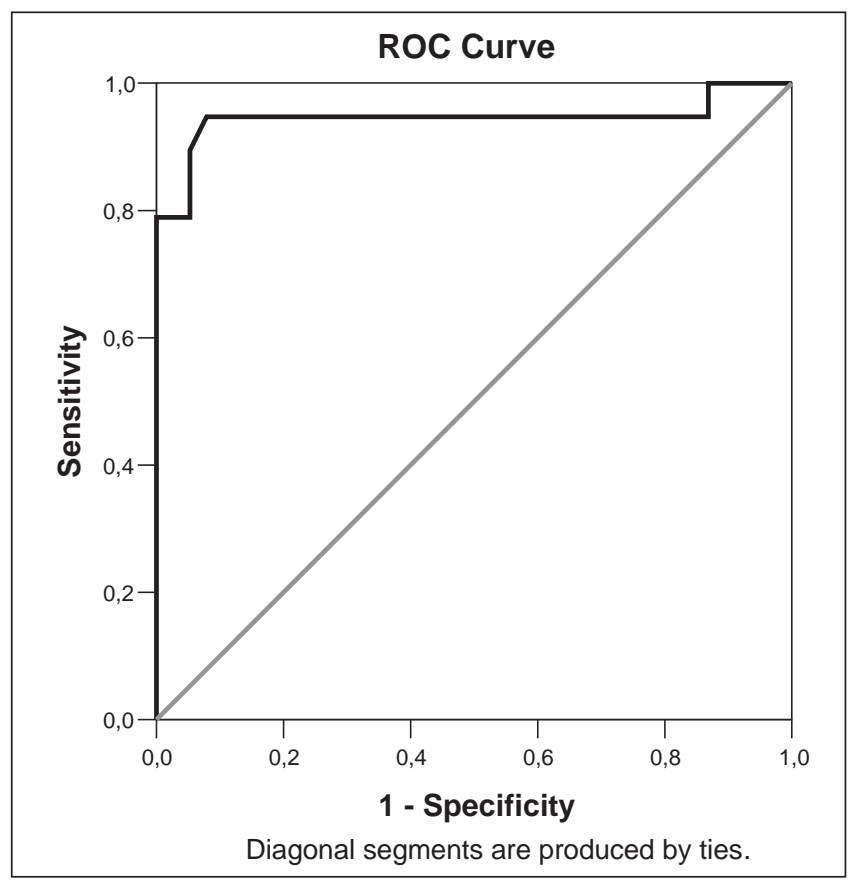

Figure 2) Receiver operating characteristic (ROC) curve in the differential diagnosis of ascites

higher in patients with congestive heart failure than in patients with liver cirrhosis $(0.88 \pm 0.25 \mathrm{cP}$ versus $0.84 \pm 0.07 \mathrm{cP}$, respectively), the difference between the groups did not reach statistical significance.

According to the results of the correlation analysis, ascitic fluid viscosity correlated significantly with ascitic fluid total protein $(r=0.718, P<0.0001)$, ascitic fluid albumin $(r=0.657$, $\mathrm{P}<0.0001)$ and ascitic fluid LDH levels $(\mathrm{r}=0.589, \mathrm{P}<0.001)$. Multiple linear regression analysis revealed that only the ascitic fluid total protein level was an independent predictor of ascitic fluid viscosity $(\beta=0.718, P<0.001)$. The sensitivity, specificity and positive and negative predictive values of ascitic fluid viscosity for the discrimination between ascites due to portal hypertension-related and nonportal hypertension-related causes according to the SAAG were determined by ROC analysis. Regarding the cut-off value of $1.03 \mathrm{cP}$, ascitic fluid viscosity measurement showed a high sensitivity and specificity (98\% and $80 \%$, respectively), and positive and negative predictive value (79\% and $94 \%$, respectively) for the discrimination of ascites etiologies (Figure 2).

\section{DISCUSSION}

There have been great advances not only in the understanding of the pathogenesis but also in the management of ascites over the past decades. SAAG is an important physiological parameter that largely depends on oncotic and hydrostatic pressure gradients between the intravascular area and serous cavities. Previous studies have found the SAAG to be $11 \mathrm{~g} / \mathrm{L}$ or greater in the presence of portal hypertension and $11 \mathrm{~g} / \mathrm{L}$ or less in its absence, with an accuracy of more than 95\%. Nevertheless, the SAAG is not an ideal parameter and has demonstrated some insufficiencies. The results of SAAG testing may be misleading and lead to difficulties in interpretation, especially in cases of peritoneal carcinomatosis, massive liver metastases, hepatocellular carcinoma and peritoneal carcinomatosis with accompanying portal hypertension. In nearly one-half of patients with malignancies, ascites develops due to an invasion of the visceral or parietal peritoneum. However, in $30 \%$ of cancer patients, ascites development is the result of liver invasion, portal venous compression or a combination of both. Conflicting results can also be obtained in nephrotic syndrome patients with very low serum albumin levels, and in shock and hepatorenal syndrome patients with decreased peripheral vascular resistance. Additionally, calculation of SAAG requires both ascitic fluid and serum samples. Therefore, while many ascitic fluid tests have been proposed as useful in the past, most of these tests have been found to be more confusing, expensive and complex, and have since been abandoned $(4,7,8)$.

In the present study, the mean ascitic fluid viscosities were $0.86 \pm 0.12 \mathrm{cP}$ and $1.22 \pm 0.25 \mathrm{cP}$ in patients with an SAAG of greater than $11 \mathrm{~g} / \mathrm{L}$ and an SAAG of $11 \mathrm{~g} / \mathrm{L}$ or less, respectively; the difference between the groups was statistically significant $(\mathrm{P}<0.001)$. Multiple linear regression analysis revealed that only the ascitic fluid total protein level was an independent predictor of ascitic fluid viscosity $(\beta=0.718, P<0.001)$. The sensitivity, specificity and positive and negative predictive values of ascitic fluid viscosity for the discrimination of ascites due to portal hypertension- and nonportal hypertension-related causes according to the SAAG were determined by ROC analysis. Regarding the cut-off value of $1.03 \mathrm{cP}$, ascitic fluid viscosity measurement demonstrated a high sensitivity and specificity (98\% and $80 \%$, respectively) and positive and negative predictive value (79\% and $94 \%$, respectively) for the discrimination of ascites. Our results show that the measurement of ascitic fluid viscosity strongly correlates with SAAG measurement in categorizing ascites according to the presence or absence of portal hypertension.

It is well known that infection of ascitic fluid does not lead to increased protein content, unlike the case in bacterial infections of other body fluids. In our study, we were also unable to demonstrate an association between ascitic fluid viscosity and ascitic fluid leukocyte count, and the presence of ascitic fluid infection. Despite the low concentration of bacteria in infected ascites, the resultant inflammatory response is considerable. Increased polymorphonuclear leukocyte counts and other released cytokines could result in serious hemodynamic changes. Lack of influence of the ascitic fluid leukocyte count and ascitic fluid infections on ascitic fluid viscosity can be explained by the negligible hemorheological effects of leukocytes, leukocyte subgroups, and the resulting hemodynamic and vascular permeability changes. In addition, the low proportion of patients with ascitic fluid infection in the present study could also have influenced these results (9).

Viscosity can be described as the resistance of fluids to flow and is one of the fundamental properties of a fluid that determines the nature of its flow. The study of viscosity is known as rheology. Measurement of fluid viscosity is very easy. Whole blood and plasma viscosity measurements are the two main clinical applications of hemorheology. It has been shown that alterations in plasma viscosity contribute to impaired blood flow and increased cardiovascular risk, and can also be considered an acute phase reactant. Plasma viscosity is determined largely by plasma proteins, more intensely hydrophilic proteins with high molecular weight such as fibrinogen, lipoproteins, 
immunoglobulins and other blood-borne proteins. On the other hand, the effects of these proteins on plasma viscosity are not solely due to molecular weight but also their concentrations, shapes and rigidity. Considering the suggested mechanisms of ascites formation, viscosity measurement has some theoretical advantage over the SAAG. Measurement of viscosity is rapid, simple, inexpensive and requires very small sample volumes $(4,10-13)$.

To our knowledge, these are the first data in the literature to suggest a diagnostic utility for ascitic fluid viscosity measurement. In a Turkish study, Yetkin et al (6) reported that the viscosity of pleural exudative effusions was higher than that of transudative pleural effusions, with high sensitivity. The increment of total protein and albumin concentrations in infected pleural fluid could explain the increased pleural viscosity. In 1973, Kellner et al (14) reported that the viscosity of ascites had a signifcant effect on treatment response. In a recent Turkish study, Akay et al (15) evaluated the reabsorption rates of ascites in decompensated liver cirrhosis patients and reported a mean ascitic fluid viscosity of $1.07 \pm 0.07 \mathrm{cP}$ (range $0.99 \mathrm{cP}$ to $1.17 \mathrm{cP}$ ), which was found to be highly negatively correlated with the ascites reabsorption rate.

\section{REFERENCES}

1. Runyon BA. Approach to the patient with ascites. In: Yamada T, Alpers DH, Kaplowitz N, et al, eds. Textbook of Gastroenterology, Volume 1. Philadelphia: Lippincott, Williams and Wilkins: 2003: 948-72.

2. Stephanie M, Rosenberg PA-C. Palliation of malignant ascites. Gastroenterol Clin N Am 2006;35:189-99.

3. Enck RE. Malignant ascites. Am J Hosp Palliat Care 2002;19:7-8.

4. Runyon BA, Montano AA, Akriviadis EA, Antillon MR, Irving MA, McHutchison J. The serum-ascites albumin gradient is superior to the exudate - transudate concept in the differential diagnosis of ascites. Ann Intern Med 1992;117:215-20.

5. Lowe GD. Should plasma viscosity replace the ESR? Br J Haematol 1994;86:6-11.

6. Yetkin O, Tek I, Kaya A, Ciledag A, Numanoglu N. A simple laboratory measurement for discrimination of transudative and exudative pleural effusion: Pleural viscosity. Respir Med 2006;100:1286-90.

7. Runyon BA. Management of adult patients with ascites due to cirrhosis. Hepatology 2004:39:841-8.

8. Uriz J, Cárdenas A, Arroyo V. Pathophysiology, diagnosis and treatment of ascites in cirrhosis. Baillieres Best Pract Res Clin Gastroenterol 2000;14:927-43.
There were some limitations to the present study. First, ascitic fluid measurements were not performed on the same day as the diagnostic paracentesis and SAAG measurements, which may have altered the results. Although we were unable to access data regarding ascitic fluid viscosity measurements and changes in viscosity measurements in frozen samples, a population study by Woodward et al (16) found that measurement of plasma viscosity in thawed frozen samples stored for up to 12 months could be achieved with similar accuracy to fresh plasma samples. However, the present pilot study aimed to evaluate the role of ascitic fluid viscosity in discriminating between ascites resulting from portal hypertension-related and nonportal hypertension-related causes, and to compare the utility of these measurements with the SAAG.

\section{CONCLUSION}

The present study demonstrated that the measurement of ascitic fluid viscosity correlates significantly with SAAG values. In view of its simplicity, low cost, small sample volume requirement and ability for measurement of previously frozen samples, we suggest that ascitic fluid viscosity evaluation be used as an alternative or complementary method to SAAG measurement for accurate and rapid classification of ascites.

9. Runyon BA, Hoefs JC. Ascitic fluid chemical analysis before, during and after spontaneous bacterial peritonitis. Hepatology 1985;5:257-9.

10. Barnes A, Willars E. Diabetes. In: Chien S, Dormandy J, Ernst E, eds. Clinical Hemorheology. Dordrecht: Martinus Nijhoff Publishers, 1987:275-309.

11. Hutchinson RM, Eastham RD. A comparison of the erythrocyte sedimentation rate and plasma viscosity in detecting changes in plasma proteins. J Clin Pathol 1977;30:345-9.

12. Stoltz JF, Singh M, Riha P. Hemorheology in Practice. Amsterdam: IOC Press, 1999.

13. Baskurt OK, Meiselman HJ. Blood rheology and hemodynamics. Semin Thromb Hemost 2003;29:435-50.

14. Kellner R, Pesch HJ, Roesch W. Therapy-resistant ascites of extreme viscosity. Acta Hepatogastroenterol (Stuttg) 1973;20:257-61.

15. Akay S, Ozutemiz O, Kilic M, et al. Reabsorption of ascites and the factors that affect this process in cirrhosis. Transl Res 2008;152:157-64.

16. Woodward M, Lowe G, Rumley A, Imhof A, Koening W. Measurement of plasma viscosity in stored frozen samples: A general population study. Blood Coagul Fibrinolysis 2003;14:417-20. 


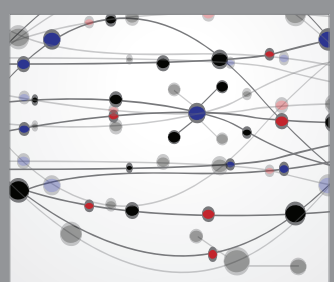

The Scientific World Journal
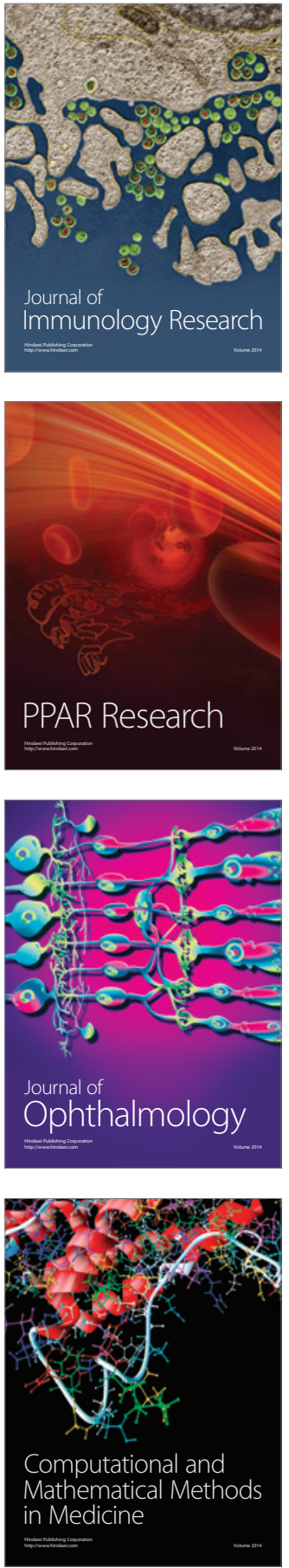

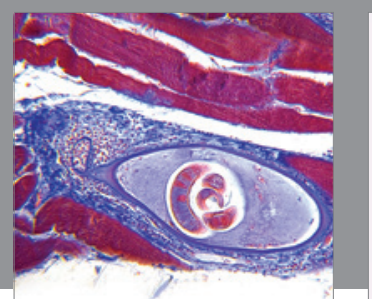

Gastroenterology Research and Practice

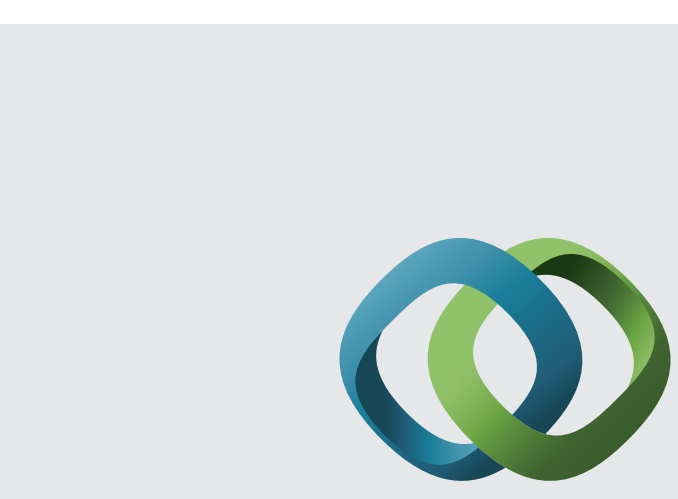

\section{Hindawi}

Submit your manuscripts at

http://www.hindawi.com
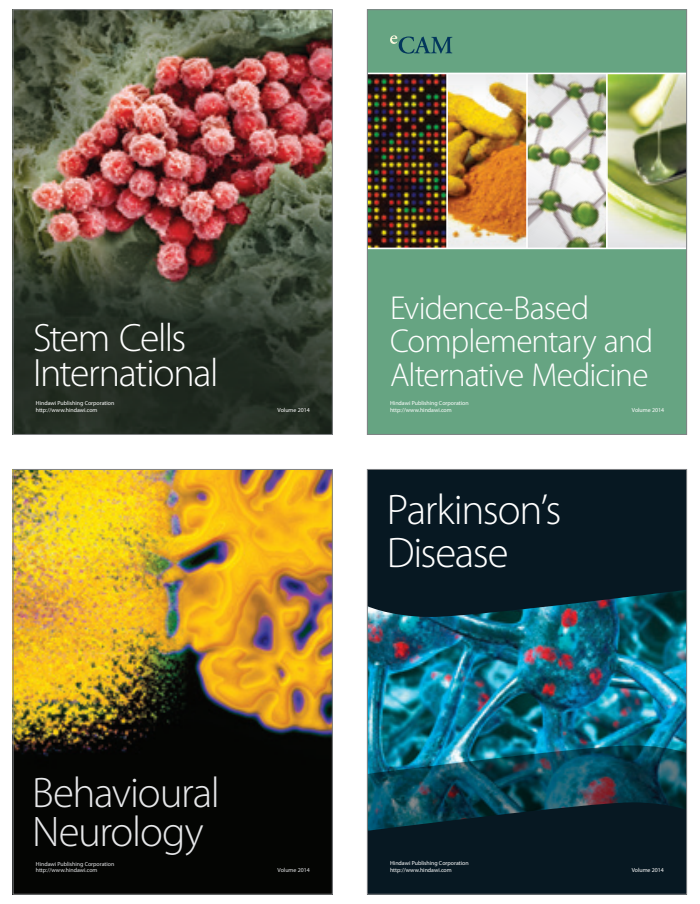
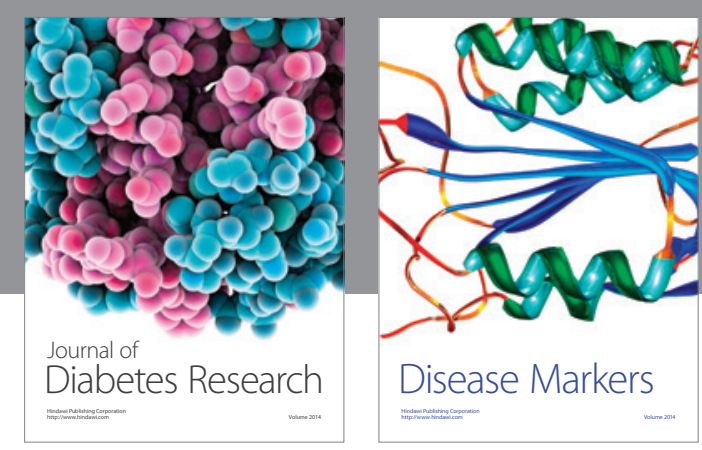

Disease Markers
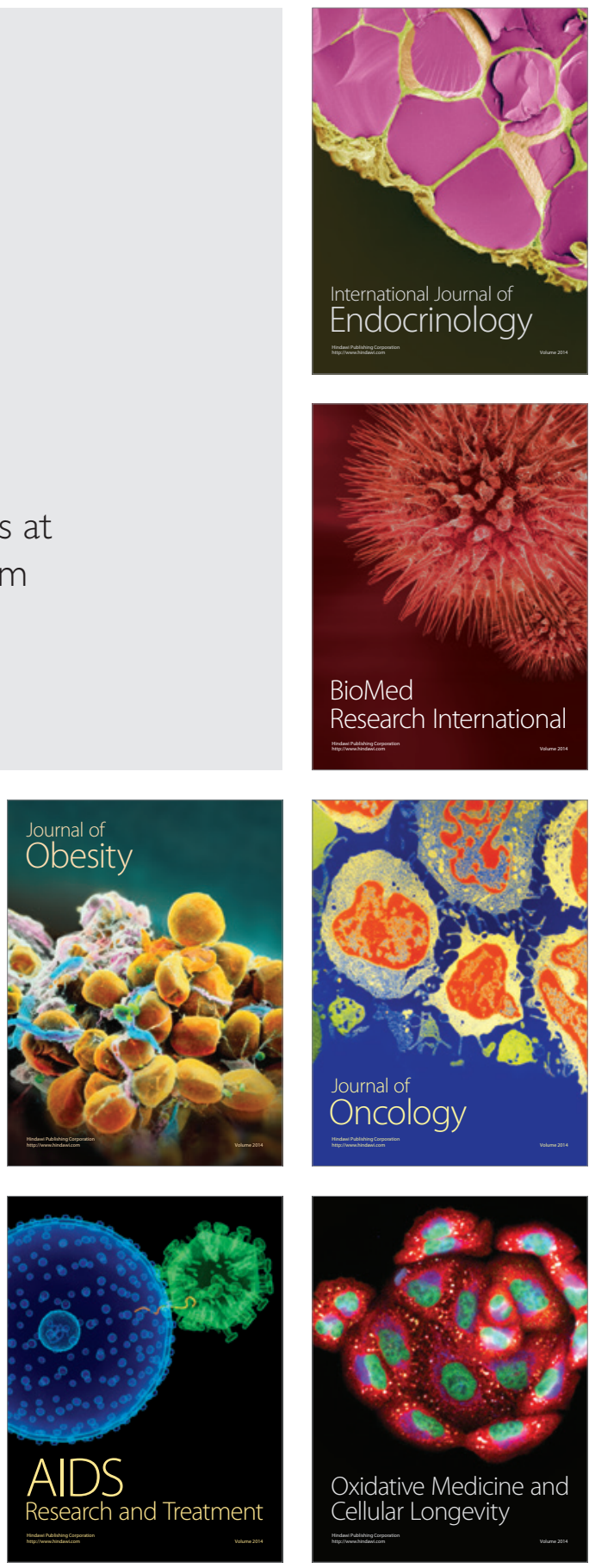